\title{
Geographic Information System-Based Spatial Analysis of Agricultural Land Suitability in Yogyakarta
}

\author{
Rika Harini, Bowo Susilo and Emilya Nurjani \\ Received: 30012015 / Accepted: 01052015 / Published online: 15022016 \\ (๑) 2015 Faculty of Geography UGM and The Indonesian Geographers Association
}

\begin{abstract}
Agricultural sector is the main economic activity of the society and also the source of people economy strengthening. The purpose of this study was to determine the priority direction of the development of the agricultural sector, mainly to determine the most appropriate types of commodities for each land unit that serve as local agricultural base. AHP method was integrated with GIS technique to analyze as well as to create land suitability maps for food crops. The results showed that 25.4 percent of lands in Yogyakarta is highly suitable for rice, while only 16 and 2 percent, respectively, is suitable for groundnut and corn. The limiting factors to the land suitability for these three commodities were plant roots condition, nutrients availability, nutrient retention, and soil condition. Suitable lands for rice, groundnut and corn were distributed at Ledok Wonosari, Middle Slope of Merapi, Lower Slope of Merapi and Batur Agung.
\end{abstract}

Keywords: Geographic Information System, Land suitability, Agricultural commodities

\begin{abstract}
Abstrak Sektor pertanian adalah kegiatan ekonomi utama masyarakat dan juga sumber penguatan ekonomi rakyat. Tujuan dari penelitian ini adalah untuk menentukan arah prioritas pengembangan sektor pertanian, terutama untuk menentukan jenis komoditas yang paling tepat pada setiap unit lahan / wilayah yang berfungsi sebagai basis pertanian lokal. Pene- litian ini dilakukan dengan menggunakan kombinasis analisis fisik dan sosial yaitu model AHP berbasis Sistem Informasi Geografi (SIG). Hasil penelitian menunjukkan bahwa 25,4 persen dari tanah di Yogyakarta sangat cocok untuk padi, sementara hanya 16 persen cocok untuk kacang tanah dan 2 persen jagung. Faktor pembatas kesesuaian lahan untuk tiga komoditas ini adalah kondisi akar tanaman, ketersediaan nutrisi, retensi hara, dan kondisi tanah. Lahan yang sesuai untuk tiga komoditas tanaman pangan tersebut terdapat di Ledok Wonosari, Lereng Tengah Merapi, Lereng Bawah Merapi dan Batur Agung.
\end{abstract}

Kata kunci: Sistem Informasi Geografi, Kesesuaian lahan, Komoditas pertanian

\section{Introduction}

Agricultural sector is largest employment providers. Most people whose main works are in agricultural sector are still traditional and domestic in scale in terms of land management. Family farms are not economically able to support viable well-being on par with other sectors in the free-trade atmosphere. Besides, the selection of agricultural commodities is also crucial to the success of the production and productivity of the agricultural sector, which will directly affect the level of farmers' income. Supportive government policies towards improving the welfare of farmers is needed, especially in the provision of agricultural inputs such as fertilizers, pesticides, seeds, irrigation system, and other agricultural inputs. Moreover, the distribution system and the determination of market price after harvest also need to be considered in order not to harm the farmers. To support this, it is necessary to assess physical as well as financial and economic viability which are the indicators of comparative and

Rika Harini, Bowo Susilo and Emilya Nurjani Faculty of Geography Universitas Gadjah Mada, Yogyakarta, Indonesia

Email: rikaharini@ugm.ac.id competitive advantage of agricultural sector in base areas of Yogyakarta Special Region. The results would allow more optimal development of agricultural sector, especially to strengthen people economy in rural areas. The objectives of this research were as follows:

1. To classify land characteristics and land quality in Yogyakarta Special Region.

2. To make spatial analysis of land suitability for agriculture, especially food crops (rice, corn, and peanuts) in Yogyakarta Special Region.

The main determinant of economic growth in a region directly relates to demands for goods and services outside that region. The growth of industries that use local resources, including labor and raw materials for export, will generate local assets and lead to (job creation). This means that export demand will establish economic linkages both backward (industrial sector) and forward (sector services) that will generate profits in the production of goods and services that have potential resources and have competitive advantage against other regions.

Seed sector is a sector that has a good prospect and can be developed to improve district/city economy or sector which wins the competition with other sectors as 
indicated by the contribution of each sector to the GDP at constant price in a region (Arsyad, 1999). Advanced analysis of seed sector is necessary to determine pattern of regional development policies. The existence of the leading sectors in a particular region have implications on the support of abundant human resource, so that the region has high comparative advantage in a particular sector. Looking at seed sector as export commodity of other areas would allow to see linkage pattern between regions and development potentials of each region.

The agricultural sector is a sector which is favored in most regions in Indonesia. This condition indicates the need for attention to the development of people, especially in rural areas. Such attention may be given by providing capital investment, both social and economic, improving agricultural productivity, establising mutually beneficial relationships between people, and generating local institutions that can empower all parties involved in productivity improvement (Sisparyadi, 2003). In the long run, agricultural sector is expected to increase to enable improvement in the economic welfare of rural people (Anonymous, 2004). Five criteria should be met to enable agricultural sector to become the dominant sector in the economy of a region. The five criteria are (1) contributive criteria: direct contribution to the national goals achievement, i e. the most effective in lowering poor population; (2) articulate criteria: is the ability to push the growth of other economic sectors of through synergistic linkages between industries; (3) promotive criteria: the ability to create an environment conducive to growth and development of other economic sectors; (4) progressive criteria: the ability to sustainably grow at a high enough rate, and (5) toughness criteria: the capacity to endure in the face of any shocks caused either by economic, social or political turmoil. By meeting these five criteria, agricultural sector would have both comparative and competitive advantage in the global economy (Simatupang et al., 2001).

Competitive advantage is a financial assessment according to which a country will be able to compete with other countries if it has a better financial terms. According to Adam Smith, a country has a competitive advantage if it has natural advantage of availability of resources, and developed advantage in form of skills in producing a commodity (Chacholiades, 1990), according to Monke and Scott (1995). Comparative advantage theory says that a country should specialize and export goods from which, in the context of cost, that country would get profit for its ability to export these particular goods with lower production costs compared to other countries (Basri, 1992). Comparative advantage may create a specialization in a particular commodity. Countries that have lower alternative costs (opportunity cost) for a particular commodity has comparative advantage in that commodity and comparative loss in other commodities (Chacholiades, 1990).

Land suitability is an assessment and classification of a piece of land in terms of its fitness for a defined use. Land suitability is assessed by comparing quality of land and land use requirements. This study assessed the suitability of actual land for three types of agricultural crops: rice, corn, and groundnut.

Land suitability classification system in this study referred to FAO system (1976), which can hierarchically be divided into four categories: suitability of land at order level, land suitability at class level, land suitability at subclass level, and land suitability at unit level. This study used land suitability at subclass level. The FAO's four categories of land suitability are presented in Table 1.

Rice is a plant that produces staple food for the people of Indonesia. The need for rice as staple food increases by years with population growth. While our rice production is not able meet people need for rice, many productive agricultural lands are used for nonagricultural activities. To meet people need for rice, new areas potential to grow rice need to be found. Banyudono Sub-district in Boyolali District has lands suitable for rice. There are two classes of land suitability for rice in this area: moderately appropriate (S2) and marginally appropriate (S3) (Rifa'i, 2011).

West Southeast Maluku, the Selaru Island, to be precise, has areas suitable for rice (28,312 hectares), corn (19,330 hectares), and groundnut (19,330 hectares) beside other plants including green bean, potato, and coconut, and areas which are not suitable for rice $(3,905$ hectares), corn (12,887 hectares), and groundnut $(12,887$ hectares) (Sirappa, et al., 2009). Rice is not only fit in Indonesia, but also in other countries, including Turkey. Research conducted in Turkey showed that 79 percent of the research areas of agricultural land was suitable for rice plants, while 21 percent was not (Ismail \& Orhan, 2014).

Corn is a food crop that can be used as a substitute for rice. Corn can be grown easily in Indonesia because it does not require any special conditions. To meet the demand for corn, areas potential for corn need to be developed. The following areas are potential for corn:

In Buven Digul District, the area suitable for corn development both on dry land and wetlands is 2,127,247 hectares (86.9 percent) with different land suitability classifications: very suitable (S1) covering an area of 490,810 hectares, moderately suitable (S2) 1,103,335 hectares, and marginally suitable (S3) 533,112 hectares. Corn can be grown once a year at the end of rainy season. There are some constraints in developing rize in moderately suitable lands (S2) including seasonal flooding and slope area, while in marginally suitable lands (S3) the constraint is steep slope (8 to15 percent). The limiting factors of not suitable lands $(\mathrm{N})$ are inundation and sulfur content of $>15$ percent (Djufry and Sosiawan, 2011).

Corn may also be suitably developed in Blitar District in East Java Province. There are three classes of land suitability for corn crops in this particular region: 
85 percent, 10 percent, and 5 percent of the total area of 150,961 hectares are highly suitable, moderately suitable, and marginally suitable, respectively. The moderately suitable lands are located in North Blitar area, while the marginally suitable are situated at an altitude of over 1,200 meters above sea level including parts of Wlingi Sub-district (10 hectares), Gandusari Sub-district (117 hectares), and Doko Sub-district (52 hectares) (Wirosoedarmo et al., 2011)

Groundnut is used as raw materials in food industry and that the needs of groundnut will increase from year to year. To meet these needs it is necessary to develop areas potential for cultivating groundnut. There is an area in West Java which is suitable for groundnut. Its land suitability is currently low to moderate, whereas from 1999 to 2001 the productivity of groundnut in this region was moderate to high. This potentially good area to develop groundnut production is located in the northern part of West Java, i.e. in Bogor, around Tinarjaya, to be precise (Hidayat and Agus, 2004). This is in contrast with the results of the study of land suitability in East Amhara Highland of Ethiopia. The research results showed that the area was not suitable for groundnut, and this included an area of 1,562,993 ha or approximately 83.26 percent (Ayalew, 2015).

Geographic Information System is a computerbased system that enables to handle geographically referenced data including data inputing, management, manipulation and analysis, and output of data (Aronoff, 1989). There are two types of digital data models in GIS: raster and vector formats. Raster model is a data model which displays, places, and stores spatial data with matrix structures that form a grid. Vector data model is a model of spatial data which displays, places, and stores spatial data using points, lines, curves, or polygons and their attributes (Prahasta, 2001). GIS is widely used in various fields of science one of which is to map land suitability, especially for agriculture. With the help of GIS data analysis process can be done digitally in faster and better ways with relatively greater data storage capacity compared to manual data.

\section{The Methods}

The study locations in Yogyakarta Special Region

Table 1. Land Suitability Classification of FAO

\begin{tabular}{|c|c|c|c|c|}
\hline \multicolumn{5}{|c|}{ Land Suitability Level } \\
\hline Order & & Class & Subclass & Unit \\
\hline Global condition & $\begin{array}{l}\text { S (suitable), a land } \\
\text { possible for sus- } \\
\text { tained use with no or } \\
\text { little risk of damage. }\end{array}$ & $\begin{array}{l}\text { S1 (highly suit- } \\
\text { able), a land that } \\
\text { has no significant } \\
\text { limitations to sus- } \\
\text { tained application } \\
\text { of a given use, or } \\
\text { only minor limita- } \\
\text { tions that will not } \\
\text { significantly reduce } \\
\text { productivity or ben- } \\
\text { efits and will not } \\
\text { raise inputs above } \\
\text { an acceptable level. } \\
\text { S2 (moderately suit- } \\
\text { able), a land that has } \\
\text { limitations which } \\
\text { in aggregate are } \\
\text { moderately severe } \\
\text { for sustained ap- } \\
\text { plication of a given } \\
\text { use; the limitations } \\
\text { will reduce produc- } \\
\text { tivity or benefits. }\end{array}$ & $\begin{array}{l}\text { Differentiated on the } \\
\text { basis of its limita- } \\
\text { tions or the kinds of } \\
\text { required improve- } \\
\text { ments. Each class can } \\
\text { be divided into one } \\
\text { or more sub-class- } \\
\text { es depending on } \\
\text { the existing types of } \\
\text { limitations, and each } \\
\text { subclass may have } \\
\text { one or more types } \\
\text { of limitations, with } \\
\text { the most dominant } \\
\text { limitation put first. } \\
\text { The types of lim- } \\
\text { itations and the } \\
\text { symbols used are } \\
\text { as follows: } \mathrm{t}= \\
\text { temperature; } \mathrm{w}= \\
\text { water availability; } \mathrm{r}= \\
\text { rooting condition; } \mathrm{f} \\
=\text { nutrient retention; } \\
\mathrm{n}=\text { nutrient avail- } \\
\text { ability; } \mathrm{x}=\text { toxicity; } \\
\mathrm{s}=\text { soil; } \mathrm{i}=\text { flooding } \\
\text { and inundation; and } \\
\mathrm{e}=\text { erotion }\end{array}$ & $\begin{array}{l}\text { Land suitability } \\
\text { condition under } \\
\text { subclasses which } \\
\text { are based on addi- } \\
\text { tional properties in- } \\
\text { fluencing land use. }\end{array}$ \\
\hline
\end{tabular}




\begin{tabular}{|c|c|c|c|c|}
\hline \multicolumn{5}{|c|}{ Land Suitability Level } \\
\hline Order & & Class & Subclass & Unit \\
\hline & & $\begin{array}{l}\text { S3 (marginally suit- } \\
\text { able), a land that has } \\
\text { limitations which in } \\
\text { aggregate are severe } \\
\text { for sustained ap- } \\
\text { plication of a given } \\
\text { use and will so re- } \\
\text { duce productivity or } \\
\text { benefits, or increase } \\
\text { required inputs, } \\
\text { that this expendi- } \\
\text { ture will be only } \\
\text { marginally justified. }\end{array}$ & $\begin{array}{l}\text { The types of lim- } \\
\text { itations and the } \\
\text { symbols used are } \\
\text { as follows: } \mathrm{t}= \\
\text { temperature; } \mathrm{w}= \\
\text { water availability; } \mathrm{r}= \\
\text { rooting condition; } \mathrm{f} \\
=\text { nutrient retention; } \\
\mathrm{n}=\text { nutrient avail- } \\
\text { ability; } \mathrm{x}=\text { toxicity; } \\
\mathrm{s}=\text { soil; } \mathrm{i}=\text { flooding } \\
\text { and inundation; and } \\
\mathrm{e}=\text { erotion }\end{array}$ & \\
\hline & $\begin{array}{l}\text { N (Not suitable), a } \\
\text { land which has qual- } \\
\text { ities that appear to } \\
\text { preclude sustained } \\
\text { use of the kind un- } \\
\text { der consideration. }\end{array}$ & $\begin{array}{l}\text { N1 (currently not } \\
\text { suitable), a land } \\
\text { that has limitations } \\
\text { which may be sur- } \\
\text { mountable in time } \\
\text { but which cannot be } \\
\text { corrected with exist- } \\
\text { ing knowledge at } \\
\text { currently acceptable } \\
\text { cost; the limitations } \\
\text { are so severe as to } \\
\text { preclude successful } \\
\text { sustained use of the } \\
\text { land in the given } \\
\text { manner. }\end{array}$ & & \\
\hline & & $\begin{array}{l}\text { N2 (permanently } \\
\text { unsuitable), a land } \\
\text { that has permanent } \\
\text { limitations which } \\
\text { appear so severe } \\
\text { as to preclude any } \\
\text { possibilities of suc- } \\
\text { cessful sustained } \\
\text { use of the land in } \\
\text { the given manner. }\end{array}$ & & \\
\hline
\end{tabular}

were determined with purposive sampling. The study collected primary and secondaty data. For the analysis of land suitability and adequacy of food, the primary data collected included (1) maps of landforms and land use which were obtained from image interpretation; (2) data including organic matter, drainage, texture, soil depth, CEC, base saturation, $\mathrm{pH}$, salinity which were obtained from observations and measurements in the laboratory; and (3) slope, rock. The secondary data used in the analysis of land suitability included images, Indonesian Topographic maps, climate data including rainfall and temperature data obtained obtained from the rain station.

The analysis to determine development priority in the agricultural sector was based on physical factors which information was obtained through geographic information system techniques by utilizing data on climate, temperature and rainfall and soil data. Slope map and terrain map overlays and landforms were used to generate land units map. The next step was the analysis of soil samples obtained in the field which were further analyzed in the laboratory to determine physical properties of the soil on research locations. The data were then matched with land unit map and administrative map of the RBI map so that which locations were (highly, moderately, marginally) suitable or unsuitable suitable for agricultural activities, particularly for food crops (rice, groundnut, and corn) 


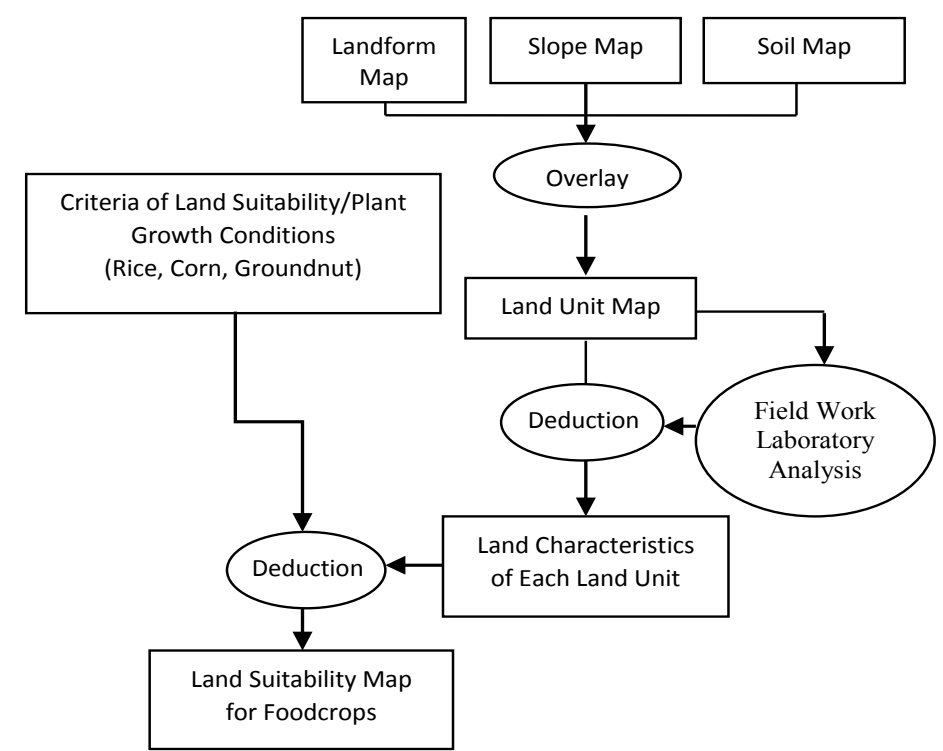

Figure 1. Land suitability for foodcrops determination process

sub-sector. The steps taken in this study can be seen in Figure 1.

\section{Result and Discussion}

Land Suitability For Rice

Rice can be grown in tropical to the sub-tropical areas, from lowlands to an altitude of 1,700 meters above sea level. In addition to a lot of water and regular fertilization, rice also requires open space that receives a lot of sunlight in order to grow well. Rice can grow at an optimum temperature of between $24^{\circ} \mathrm{C}$ and $29^{\circ} \mathrm{C}$, but the best temperature is $23^{\circ} \mathrm{C}$ with an average rainfall of $200 \mathrm{~mm}$ per month or 1500 to $2000 \mathrm{~mm}$ per year or more with four month distribution. Land suitable for rice should have a depth of more than $60 \mathrm{~cm}$ with thickness of top layer soil of between 18 and $22 \mathrm{~cm}$, the drainage is blocked, with argillaceous sand to clay texture, and soil reaction $(\mathrm{pH})$ of between 5.5 and 7.0. Rice can grow in an area with a lot of hot air and water vapor. In the research area, rice was cultivated in plain areas which irrigation was supplied by the existing irrigation system so that it can be grown two or three times a year. In areas with no irrigation system, rice is usually grown once a year only.

The evaluation results of land suitability for rice by unit of land in the studied locations suggest that the distribution of land suitability for rice ranged from S1 (highly suitable) to $\mathrm{N}$ (not suitable). The distribution in details was as follows: 25,4 percent was highly suitable, 18 percent was moderately suitable, 42.1 percent was marginally suitable, and 14.6 percent was not suitable. The existing limiting factors of land suitability subclasses were rooting condition $(\mathrm{r})$, the availability of nutrients $(\mathrm{n})$, nutrient retention $(\mathrm{r})$, terrain $(\mathrm{s})$, and floods and inundation (i).

Total areas with unsuitable lands for rice was 45,736.1 hectares and distributed in 43 sub-districts in four districts in Yogyakarta Special Province. Some sub-districts with not suitable order for rice were Gedangsari, Girisubo, Samigaluh, and Kalibawang, while areas with highly suitable order for rice included 79,869.9 hectares and distributed in 58 sub-districts throughout Yogyakarta Special Region.

Based unit of land, areas suitable for wetland rice cultivation had slope class I, i.e. between 0 and 2 percent, while areas which are not suitable for rice are generally located in areas with slope class between the IV-VI ranging from 15 percent to above 40 percent . The largest land unit for the rice was V5AI with area coverage of $41,750.9$ hectares or 52.3 percent of all land units suitable for rice.

V5AI land unit was found in lower slope of Merapi with alluvial soil type and slope of between 0 and 2 percent. The largest areas of land units which were not suitable for rice were K1MEV and K1MEVI, 13,997.7 and $13,171.5$ hectares, respectively. Compared to the overall areas not suitable for rice, the corresponding percentages were 30.6 percent and 28.8 percent, respectively. These land units were located in the Sewu Highlands with mediterranean soil types and slopes ranging from 25 percent to over 40 percent. In more details, the areas in Yogyakarta Special Province suitable for rice can be seen in Figure 2.

\section{Land Suitability For Corn}

Corn needs fertile and crumbly soil with good drainage and aeration to grow well. without good drainage and soil aeration corn growth will be interrupted and the prodution will be affected. The best $\mathrm{pH}$ or acidity level is between 5,5 and 7,0. The desired slope is not more than 8 percent. Enough sunlight is indispensable to plant corn, because less sunlight will result in less production as well. The optimum temperature is between 20 and 27 Celcius, although it 


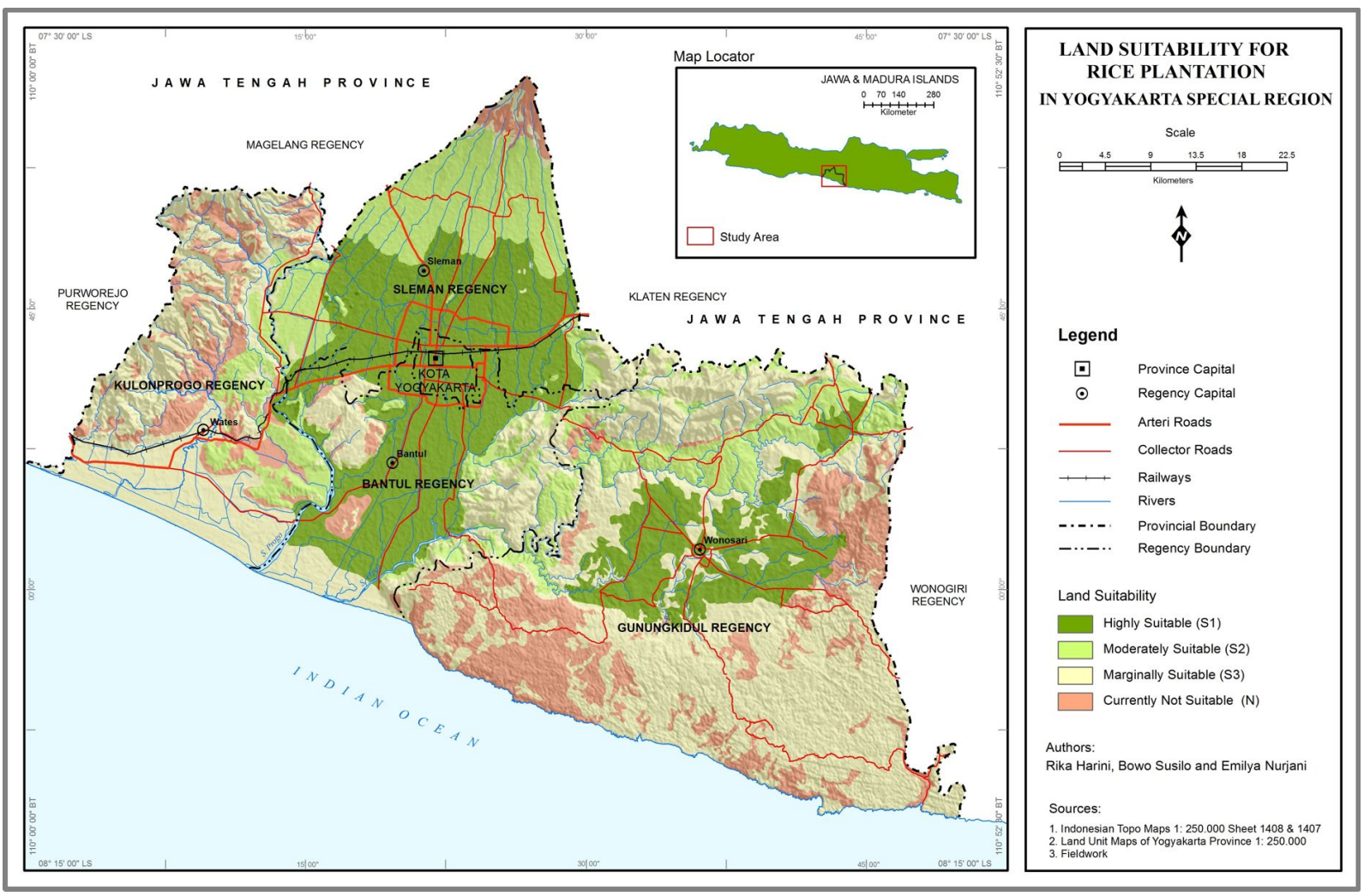

Figure 2. Map of lands suitable for rice in Yogyakarta Special Region

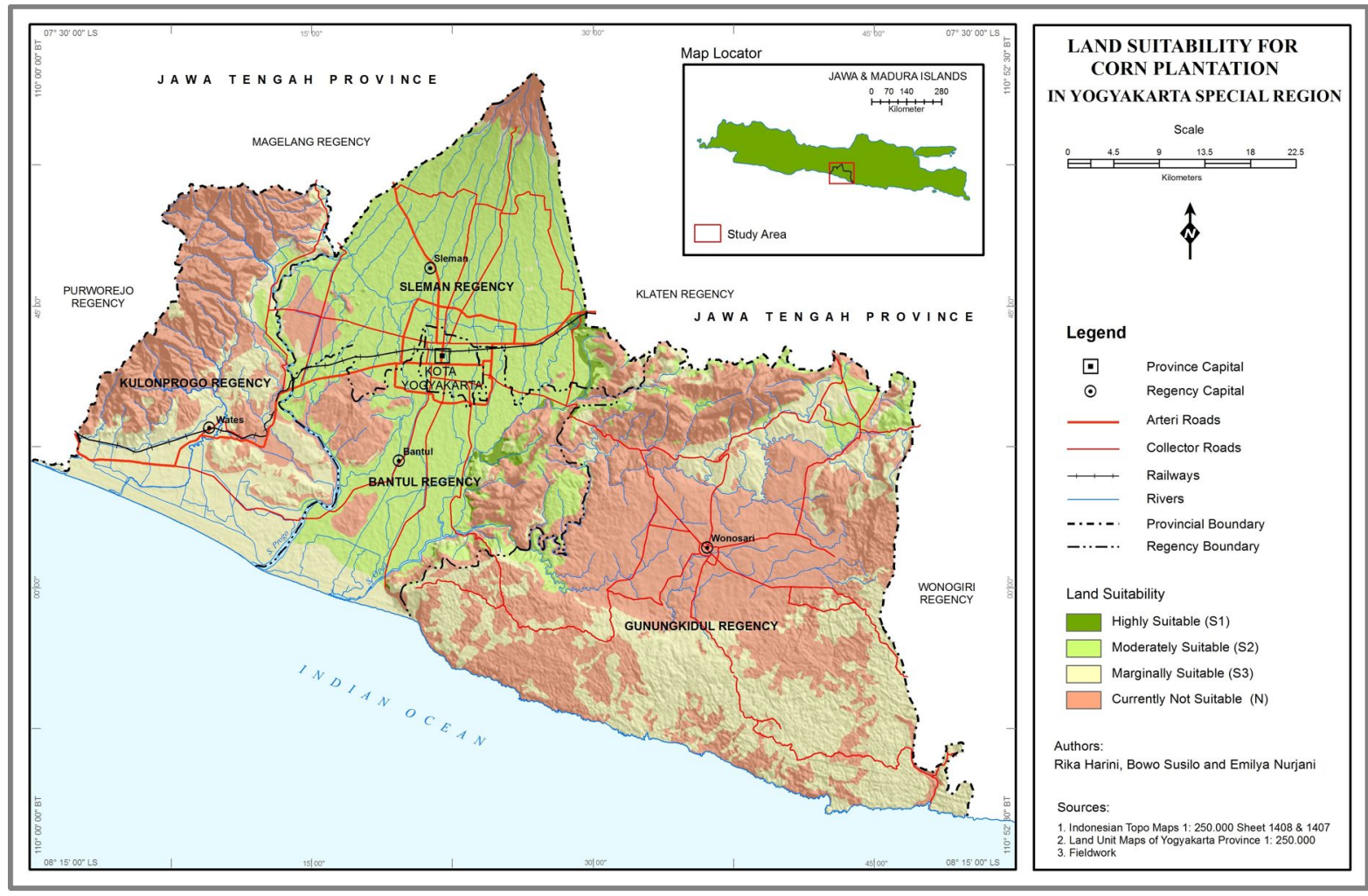

Figure 3. Map of lands suitable for corn in Yogyakarta Special Region 
could still grow at temperatures as low as 16 Celcius or as high as $320 \mathrm{C}$. The rainfall may range from 500 to 5000 milimeters per year, whil while the optimum is between 1000 and 1500 milimeter per year. In the study location, corn was generally grown on moor lands, mixed garden, and on the rice fields by providing contours and drying with water management. Some people applied intercropping sistem by planting corn simultaneously with other crops, and some did not.

The classification results of land suitability for corn suggest that the distribution of land suitability for corn ranged from highly suitable to not suitable. The distribution in details was as follows: 58 percent was not suitable, 25 percent was marginally suitable, 15 percent was moderately suitable, and 2 percent was highly suitable. The existing limiting factors of land suitability subclasses were rooting condition ( $r$ ), the availability of nutrients $(\mathrm{n})$, nutrient retention $(\mathrm{r})$, terrain $(\mathrm{s})$, and floods and inundation (i).

Total areas not suitable for corn was $135,720.3$ hectares, while areas suitable for corn was $1,789.3$ hectares. The remaining area consisted of moderately suitable and marginally suitable lands amounting of 177,287.1 hectares. Areas suitable for corn included parts pf Banguntapan, Imogiri, Jetis, Kalasan, Kretek, Patuk, Piyungan, Pleret, Prambanan, and Pundong Sub-districts. Sub-districts with lands not suitable for corn included parts of Dlingo, Kokap, Nanggulan, Panjatan, and Tepus .

Based unit of land, land units suitable for corn are S3LAI with Latosol soil type and slope class I of between 0 and 2 percent and located in the hills area of Baturagung, including an area of 1,789.3 hectares. Land units not suitable for maise were S1GRI and KIMEV. S1GR1 land units are located in Wonosari Ledok with Grumusol soil type and slope class I of between 0 and 2 percent, while K1MEV land units are located in Sewu Highland with Mediterranean soil type and slope class $\mathrm{V}$ of between 25 and 40 percent. In more details, lands suitable for corn in Yogyakarta Special Region areas can be seen in Figure 3.

\section{Land Suitability For Groundnut}

Groundnut have similar requirements to that of for corn to grow well, including fertile and crumbly soil, good drainage and soil aeration, and no less important is that the land should be as free from rocks as possible. Rock contained in the soil with moderate to high density will result in low productivity because the process of groundnut flowers penetration into the soil will be interfered. In the research area, groundnut was grown on rice fields with irrigation and drainage system and moor, and some on mixed garden.

Distribution of land suitability classes for groundnut in the study area ranged from moderately suitable (S2) to not suitable $(\mathrm{N})$ classes. The distribution in more details were as follows: 16 percent was moderately suitable, 28 percent marginally suitable, and 56 percent was not suitable. The factors limiting land suitability were rooting condition (r), availability of nutrients (n), nutrient retention $(\mathrm{r})$, and terrain $(\mathrm{s})$.

Lands not suitable for groundnut included total

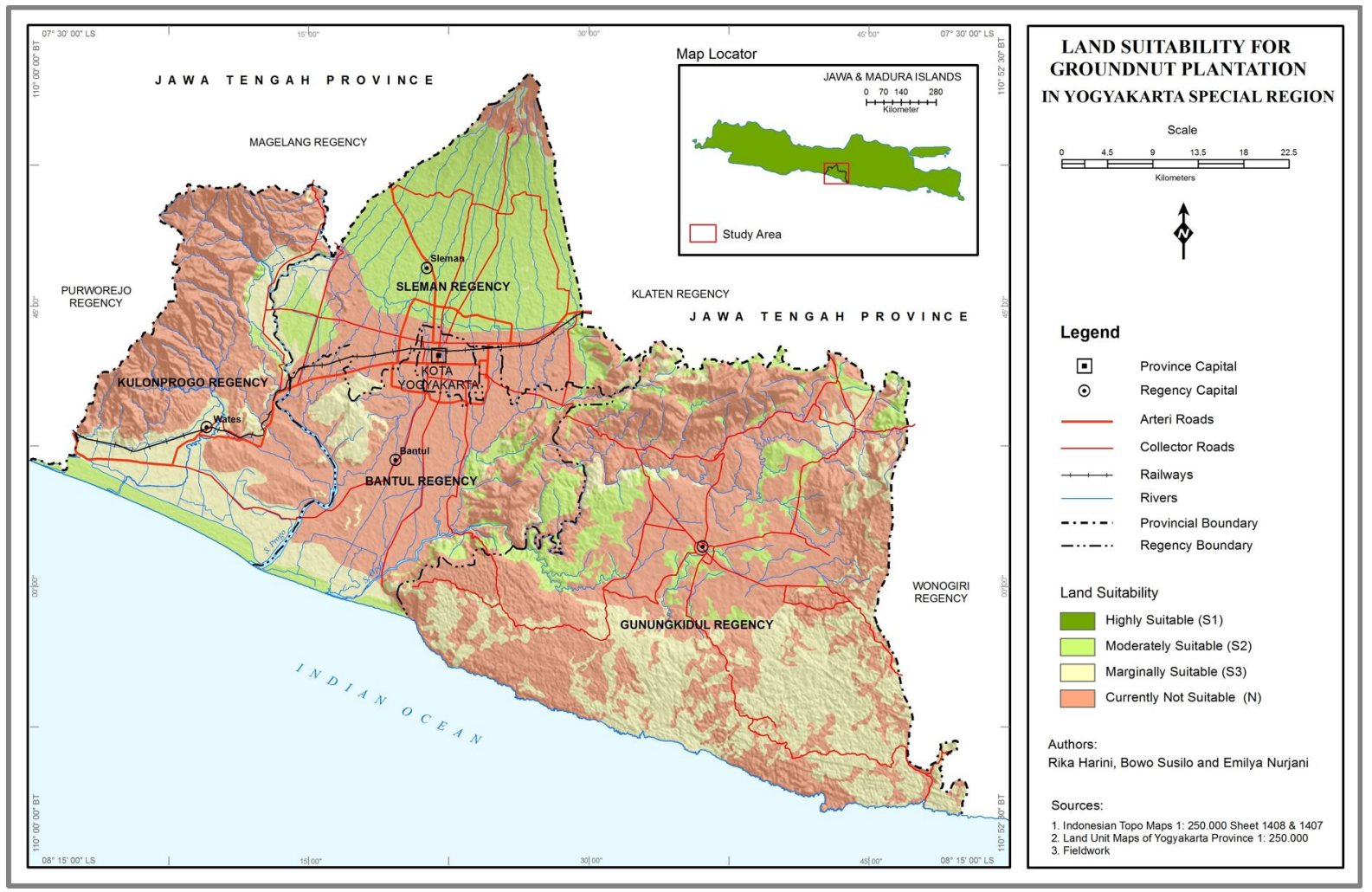

Figure 4. Map of lands suitable for groundnut in Yogyakarta Special Region 
area of 182,317.2 hrctares or 57.9 percent of the overall study area. Lands highly suitability for groundnut bean was not found in the study area, while moderately suitable and marginally suitable lands included an area of 63,012.8 hectares (20.0 percent) and 69,466.7 hectares (22.1 percent). Land unit not suitable for groundnut with Grumusol soil type and slope class I of between 0 and 2 percent was S1GRI located in Wonosari Ledok. Land units moderately suitable for groundnut with Regosol soil type and slope classes I (between 0 and 2 percent) and II (between 2 percent and 8 percent) were V4REII and V4REI located in the middle slope of Merapi. Land unit marginally suitable for groundnut with mediterranean soil type amd slope class IV of between 15 percent and 25 percent was K1MEIV located in the Sewu Highland. In more details, areas suitable for groundnut in Yogyakarta Special Region can be seen in Figure 4.

Land Units Suitability For The Three Crops

Analysis of the suitability of land for rice, corn and groundnut was done for the entire Province of Yogyakarta, so that there were several land units not suitable for the three crops, not suitable for rice and corn, not suitable for rice and groundnut, and not suitable for corn and groundnut. Based on the analysis, 14 land units were found not suitable for all crops (paddy rice, corn, and peanuts). These land units are located in Menoreh Hills, Sentolo Hills, Sewu Highland, Ledok Wonosari, Upper Slope of Merapi, and Middle Slope of Merapi. These land units were dominated by the slope classes ranging from IV to VI or 25 percent to over 40 percent. Lands not suitable for rice and corn were 15 units. These lands were located in the the same slope classes. This also applied to land units not suitable for rice and groundnut, although the number of land units was greater, i.e.16 units.

Twenty three land units not suitable for corn and groundnut were 23 and found in the same location with varying slope classes, ranging from class I (0 to 2 percent) to class VI over 40 percent. The land suitability comparison results show that there was no land unit suitable either for the all three crops (rice, corn, groundnut) or combinations of two crops-ricecorn, rice-groundnut, and groundnut-corn.

\section{Conclusion}

Based on the above discussion results, some conclusions can be drawn for the research area of Yogyakarta Special Region, including:

1. Based on the classification of lands characteristics and quality in YogyakartaSpecial Region showed that most of the region is very suitable for rice crop. This means that efforts to increase food production, especially rice can be optimized so that it will support the food security program. In the quantitative results of land suitability for crops of rice, corn and groundnut were as follows: a. Rice with in highly suitable lands was 25.4 percent, moderately suitable 18 percent, marginally suitable 42.1 percent, and not suitable 14.5 percent.

b. Corn with in highly suitable lands was 2 percent, moderately suitable 15 percent, marginally suitable 25 percent, and not suitable 58 percent.

c. Groundnut with in moderately suitable lands was 16 percent, marginally suitable 28 percent, and not suitable 56 percent.

2. Lands possibly cultivated for agricultural activities and suitable for wetland rice were located in Ledok Wonosari with Grumusol soil type and in Ledok Wonosari with Rendsina soil type, in Middle Slope of Merapi with Regosol spil type and in Lower Slope of Merapi with alluvial soil type. Lands suitable for corn was found in Batur Agung with Latosol soil type, while the suitability of land for groundnut was found in Middle Slope of Merapi with Regosol soil type and in the Sewu Mountains with Mediterran soil type.

There are some recommendations based on the analysis:

1. The use of raw data, especially map scales needs to be larger to get more detailed results. For future research, land use maps would be needed to get more detailed information about current situation of land suitability using the study results.

2. This study only examined the characteristics of research area to determine, physically, land suitability for agricultural activities, particularly foodcrop sector (rice, corn, and groundnut). Further study is thus necessary to find out how people use the existing agricultural lands, especially how they choose types of agricultural commodity.

\section{Acknowledgement}

Authors would like to thank LPPM-UGM and Directorate General of Higher Education for providing fund of research through "Competitive Grants". The authors would also like to express gratitude to Dr. Suprapto Debyo Saputro, M.Sc who helped with analysis of physical conditions, and the assistants who helped with field data collection.

\section{References}

Anonymous, (2004), Penguatan Ekonomi Rakyat: Pertanian Tanaman Pangan. Pemerintah Kabupaten Bantul. Yogyakarta

Aronoff, S., (1989), Geographic Information Systems: A Management Perspective, WDL Publications, Ottawa.

Arsyad, L., (1999), Pengantar Perencanaan dan Pembangunan Ekonomi Daerah, BPFE, Yogyakarta

Ayalew, G., (2015), A Geographic Information System Based Physical land Suitability Evaluation to Groundnut and Sweet Potato in East Amhara, Highland of Ethiopia. Journal of Biology, Agriculture and Healthcare Vol. 5, No. 1, 2015 (ISSN 2225- 
093X)

Basri, F.H. (1992), Perkembangan Terbaru Teori Perdagangan Internasional. Ekonomi dan Keuangan Indonesia. Penerbit Fakultas Ekonomi Indonesia.

Chacholiades, M. (1981), International Economics. Mc. Graw-Hill Publishing Company. New York.

Djufry, F., and Sosiawan, H., (2011), Penyusunan Peta Kesesuaian Lahan Tanaman Jagung dan Rekomendasi Teknologi Aplikatif di Kabupaten Buven Digul Papua. Seminar Nasional Serealia 2011

FAO, (1976), A Frame Work for Land Evaluation. FAO Soil Bulletin no 32. Wageningen. ILRI.

Hidayat, H. and Agus, A., (2004), Analisis Pengembangan Lahan untuk Tanaman Kacang Tanah di Jawa Barat dari Data Landsat dengan Sistem Informasi Geografis. Jurnal Penginderaan Jauh dan Pengolahan Data Citra Digital vol. 1, No. 1 Juni 2004:46-50

Monke E.A. dan Scott, R.P., (1995), The Polocy analysis Matrix For Agricltural Development. Cornall University Prress. Ithaca

Prahasta, E., (2001), Konsep - Konsep Dasar Sistem Informasi Geografi, Informatika. Bandung

Rifa'i, S., (2011), Kesesuaian Lahan Padi Sawah di Kecamatan Banyudono Kabupaten Boyolali, Skripsi, Fakultas Geografi Universitas Muhamadiyah Surakarta

Ismail, S., and Orhan, D., (2014), Application of a multicriteria decision-making approach for rice land suitability analysis in Turkey. Turkish Journal of Agriculture and Forestry 38:926-934, http:// journals.tubitak.gov.tr/agriculture/ (10.3906/tar1405-85).

Simatupang, S., et al., (2001), Sektor Pertanian Sebagai Andalan Pembangunan Ekonomi Indonesia. Bulletin Agro Ekonomi (4) Tahun 2001 hal 1-7

Sirappa, S., Pasang, M., Waas, E.D., Susanto, A.N., (2009), Land Suitability and Purposed Land Use of Selaru Island, West-Southeast Moluccas Regency. Journal Trop Soils, Vol. 15, No. 2, 2010:169-178, (ISSN 0852-257X), 10.5400/jts.2010.15.2.169

Sisparyadi, S., (2003), Kemandirian Desa Sebagai Kekuatan Otonomi Daerah. Majalah Dinamika Pedesaan dan Kawasan Vo 3 No 3 2003. Pusat Studi Pedesaan dan Kawasan UGM.

Wirosoedarmo, R., et al., (2011), Evaluasi Kesesuaian Lahan untuk Tanaman Jagung Menggunakan Metode Analisis Spasial. Jurnal Agritech Vol. 31 No. 1 Februari 2011. 